\title{
Sodium azide mutagenesis resulted in a peanut plant with elevated oleate content
}

\author{
Chuan Tang Wang ${ }^{1} \bowtie \cdot$ Yue Yi Tang ${ }^{1} \cdot$ Xiu Zhen Wang ${ }^{1} \cdot$ Shu Wei Zhang ${ }^{2} \cdot$ Gui Jie Li $^{1}$ \\ Jian Cheng Zhang ${ }^{1} \cdot$ Shan Lin $\mathrm{Yu}^{1} \otimes$ \\ 1 Shandong Peanut Research Institute, Qingdao, China \\ 2 Shandong Agricultural University, Tai'an, China
}

$\triangle$ Corresponding authors: chinapeanut@126.com; yichuanyuzhongxue@126.com

Received September 5, 2010 / Accepted December 16, 2010

Published online: March 15, 2011

(c) 2011 by Pontificia Universidad Católica de Valparaíso, Chile

\begin{abstract}
Screening of peanut seeds resulting from $0.39 \%$ sodium azide treatment with NIRS calibration equation for bulk seed samples identified a plant with more than $60 \%$ oleate. Oleate content in individual seeds of the plant, as predicted by NIRS calibration equation for intact single peanut seeds, ranged from $50.05 \% \sim 68.69 \%$. Three seeds with $>60 \%$ oleate thus identified were further confirmed by gas chromatography. Multiple sequence alignments of the FAD2B gene from Huayu 22 (wild type) and peanut seeds with elevated oleate (mutant type) revealed a C281T transition in the coding region causing an 194T substitution in the oleoyl-PC desaturase, which may be responsible for reduction in the enzyme activity.
\end{abstract}

Keywords: chemical mutant, FAD2B, NIRS, oleate, peanut

\section{INTRODUCTION}

As a rich source of oil and protein, the cultivated peanut (Arachis hypogaea L.) is an important cash crop in the world. High oleate ( $\mathrm{HO})$ peanut has several advantages over normal oleate genotypes (O'Byrne et al. 1997). Firstly, HO peanut products have prolonged shelf life. Secondly, HO diet has proved to decrease low density lipoprotein (LDL) cholesterol level in human blood. Thirdly, HO peanut is also considered more suitable for biodiesel production. Norden et al. (1987) reported the first HO peanut, F435 (a natural mutant); since then, several additional HO peanut genotypes have been reported, which provide parental materials for hybridization to transfer this valuable trait to adapted peanut cultivars (Chu et al. 2007; Yu et al. 2008; Chu et al. 2009; Wang et al. 2010). Although HO is conditioned by two major genes encoding fatty acid desaturase (FAD2A and FAD2B) (Lopez et al. 2001; Isleib et al. 2006), and may become stable in $F_{2}$ generation, other traits may keep on segregating until $\mathrm{F}_{6}$. No doubt, developing $\mathrm{HO}$ peanut varieties with acceptable productivity through hybridization is still a lengthy process.

Agronomic characters in mutated populations in most cases, on the other hand, tend to stabilize easily. Consequently, induction of quality mutants from high yielding adapted peanut cultivars seems a logical option for immediate responses to the ever-changing market demand. In crop plants like soybean, rapeseed and peanut, HO chemical mutants have been bred (Jung et al. 2000; Mondal et al. 2010). Near infrared reflectance spectroscopy (NIRS) calibration equations for oleate and linoleate in single peanut seeds has already been developed by Tillman et al. (2006), which provide a fast, accurate, and cost-effective method for selection; yet they have not been used in peanut mutation breeding.

In this paper, we reported a $\mathrm{HO}$ peanut plant selected with NIRS calibration equations for both bulk seed samples and single intact seeds, and a novel mutation in FAD2B gene. 
Wang et al.

\section{MATERIALS AND METHODS}

\section{Peanut materials}

Huayu 22, a high yielding Virginia-type peanut cultivar (export type) was used in chemical mutagen treatment. The foundation seeds were kindly provided by $\mathrm{Dr}$ Jing Chen, peanut breeder, Shandong Peanut Research Institute.

\section{Sodium azide treatment}

In spring 2008, prior to sowing, seeds in a mesh bag were firstly soaked in tap water for 4 hrs with intermittent shaking to ensure good aeration. The seeds were then taken out and excessive water was shaken off. Afterwards, the seeds were immersed in a $0.39 \%$ freshly prepared sodium azide $\left(\mathrm{NaN}_{3}\right)$ solution in $0.13 \mathrm{M}$ phosphate-buffered saline (PBS) buffer ( $\mathrm{pH} 3.0$ ) for $2 \mathrm{hrs}$ with constant agitation. After treatment, the seeds were washed in cold running water for $2 \mathrm{hrs}$.

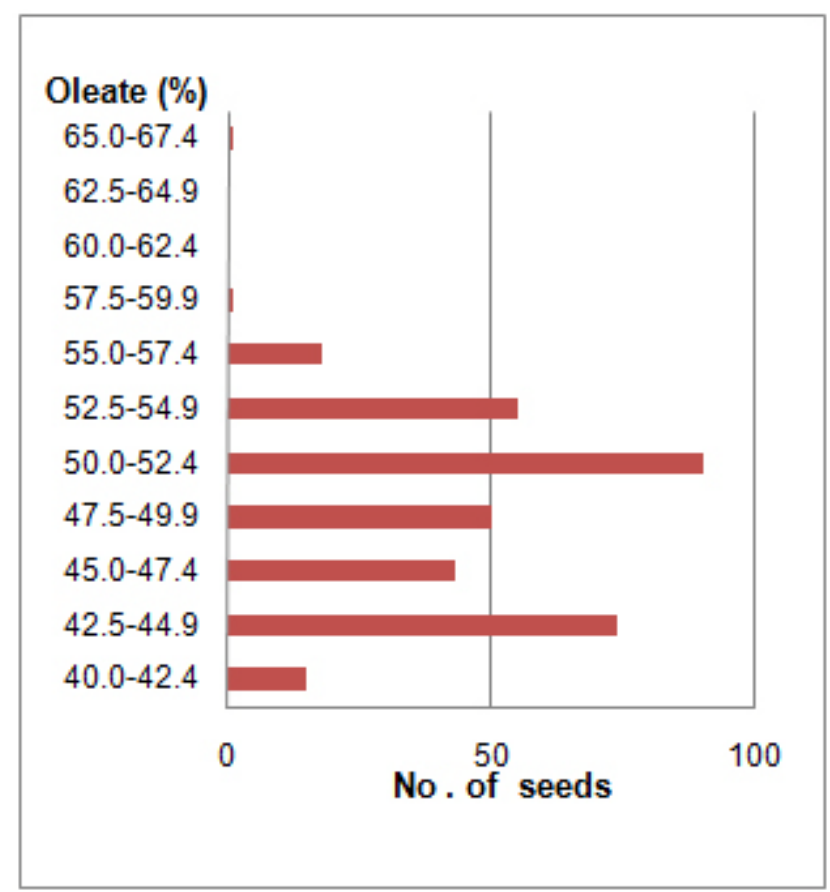

Fig. 1 Histogram of oleate content (\%) in 347 groundnut plants as predicted by the NIRS equation for bulk seed samples.

\section{Cultivation of the treated material and selection of the subsequent generations}

After 30 min of drying, the mutagenized seeds along with untreated seeds of the same variety (wild type) were planted in a twin-row seedbed with $80 \mathrm{~cm}$ bed spacing, $30 \mathrm{~cm}$ inter-row spacing and 16.67 $\mathrm{cm}$ within-row spacing under polythene mulch. The population was 15,000 plants per hectare.

In autumn 2008, only plants with extremely poor performance were discarded; other plants were harvested. In spring 2009, through in-house seed test, peanut plants with good productivity were selected to sow plant lines. Selection was made with plant types, pod shapes, the number of pods per plant and pod filling in field in autumn 2009. 


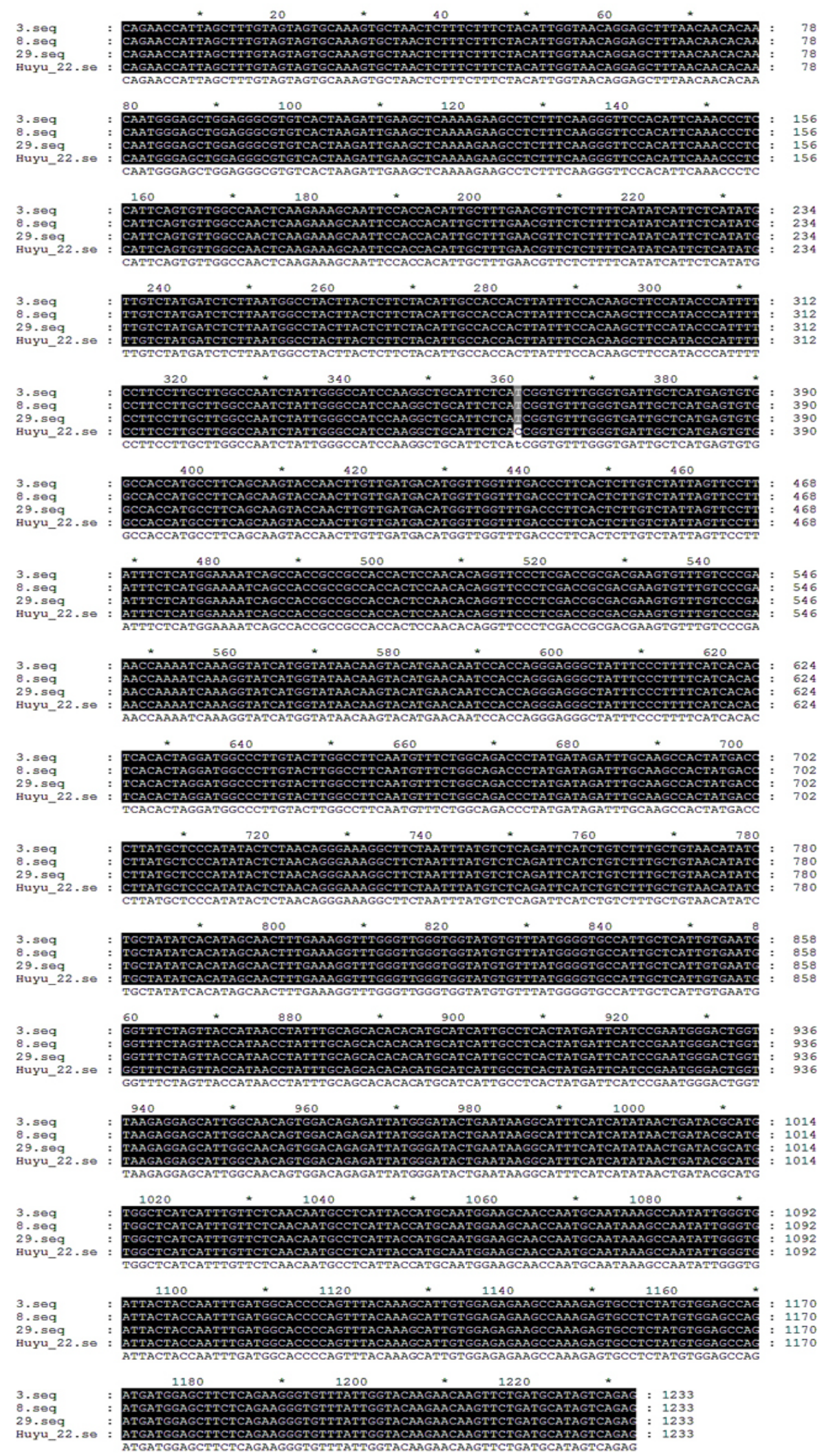

Fig. 2 Multiple alignments of $F A D 2 B$ gene from Huayu 22 and from the 3 peanut seeds with elevated oleate contents, note a $\mathrm{C}$ to $\mathrm{T}$ transition in 281 position of the coding region. 
The oleate content in sun dried peanut seeds from individual plants was estimated by NIRS (Matrix-I, Bruker Optics, Germany) based on the calibration equation for bulk seed samples, with a $\mathrm{R}^{2}$ of $89.16 \%$ and a RMSECV of $2.62 \%$, developed by the authors using 202 accessions of samples representing diverse origin, seed size and seed coat colour. The integrating sphere module has a sampling area of $20 \mathrm{~mm}$ in diameter. The internal diameter of the rotating sample cup assembly was $5 \mathrm{~cm}$. Wavenumber was $4,000-12,000 \mathrm{~cm}^{-1}$. Each seed sample was measured once.

Individual seeds from a single plant identified as with high oleate were then scanned with the same NIRS machine equipped with a small cup for a single peanut seed. The oleate content was predicted by NIRS equation for single intact peanut seeds, with a $\mathrm{R}^{2}$ of $97.20 \%$ and a RMSECV of $2.65 \%$, developed using $F_{1: 2}$ seeds from $\mathrm{HO} x$ normal oleate crosses (Wang et al. 2010). Wavenumber was $4,000-12,000 \mathrm{~cm}^{-1}$. Each seed was measured once.

\section{GC analysis of the fatty acids in single peanut seeds}

A small peanut seed portion distal to embryo end, weighing $50 \mathrm{mg}$ or more, were cut off as the starting material, whose oleate content was determined by gas chromatography (GC) as described by Zeile et al. (1993).

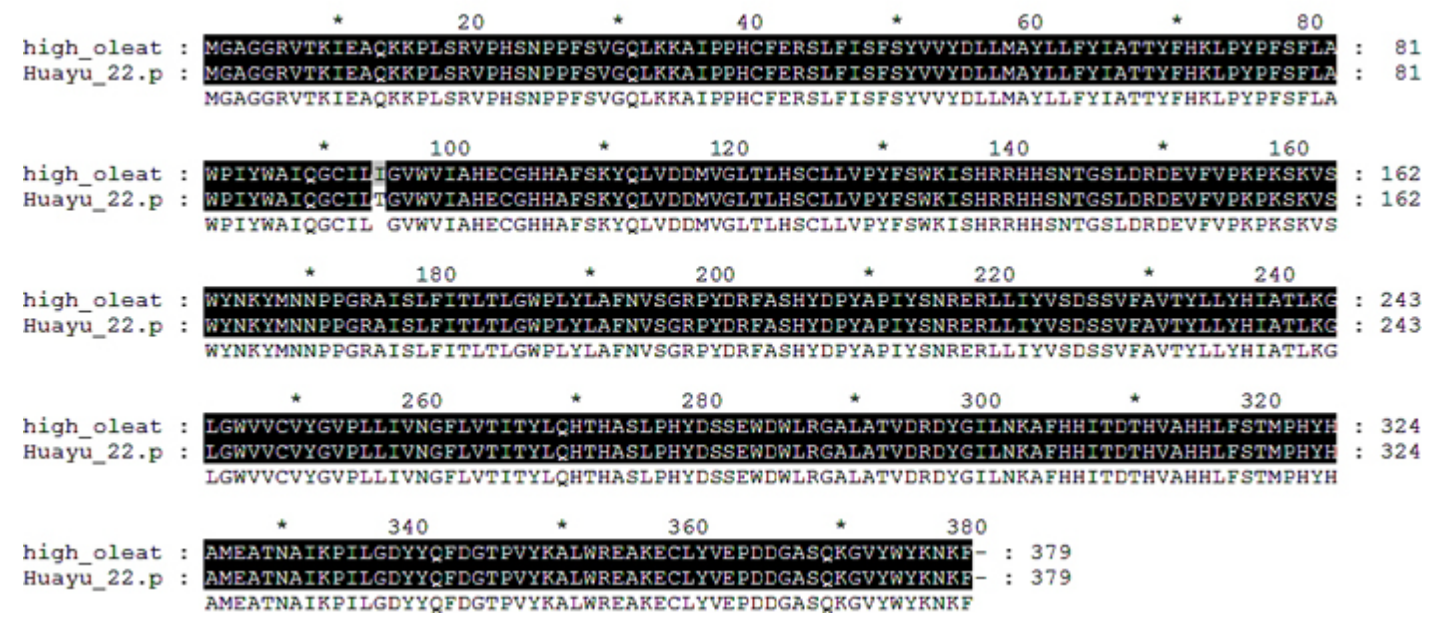

Fig. 3 Difference in amino acid sequences of $F A D 2 B$ coding oleoyl-PC desaturase from high oleate mutant and normal oleate cultivar Huayu 22, note an 194T substitution in high oleate mutant.

\section{Cloning and sequence analysis of FAD2B gene}

DNA was extracted from a slice of peanut cotyledonary tissue according to the protocol developed at our laboratory earlier (Yu et al. 2010). PCR mixture $(50 \mu \mathrm{l})$ for amplification of the FAD2B gene was made up of $25 \mu$ l of Tiangen $2 \times$ Taq platinum Master Mix (Tiangen Biotech, Beijing), $5 \mu$ l of DNA template, and $2 \mu \mathrm{l}$ of bF19/R1 PCR primers $(10 \mu \mathrm{M})$ each (Patel et al. 2004). Thermal cycling profile, run on a Tgradient thermal cycler (Biometra, Göttingen), was $95^{\circ} \mathrm{C}$ for 6 min, followed by 35 cycles of $94^{\circ} \mathrm{C}$ for $30 \mathrm{sec}, 53^{\circ} \mathrm{C}$ for $1 \mathrm{~min}$, and $72^{\circ} \mathrm{C}$ for $2 \mathrm{~min}$, and a final extension of $74^{\circ} \mathrm{C}$ for $4 \mathrm{~min}$. The PCR products were purified, ligated into a pBS-T vector (Tiangen Biotech, Beijing), and used in heat shock transformation with chemically competent TOP10 E. coli cells (Tiangen Biotech, Beijing). White colonies harbouring plasmids with inserts of expected size identified by colony PCR were used to extract plasmid DNA for sequencing with the M13 forward and reverse primers on an ABI 3730XL DNA sequencer.

Translation and multiple alignments of DNA sequences were performed using the Lasergene ${ }^{T M}$ DNAStar package (DNASTAR, Madison). Hydrophobicity was analyzed using the ProtScale program (http://www.expasy.org/cgi-bin/protscale.pl). 


\section{RESULTS AND ANALYSIS}

\section{NIRS-aided selection of peanut with elevated oleate content}

A total of 8,905 peanut seeds were treated with sodium azide in spring 2008. After in-house seed selection, 76 plant lines were sown in field in spring 2009. In spring 2010, through analysis of 347 peanut plants using the NIRS equation for bulk seed samples, a plant with elevated oleate content (66.51\%) (Plant no. 76-13D3-2) was identified (Figure 1), whose productivity in 2009 (seed weigh: $35.85 \mathrm{~g}$ ) was comparable to Huayu 22 (seed weigh: $34.34 \mathrm{~g}$ ), though further evaluation is still needed. Considering possible heterologous $\mathrm{HO}$ genotype, single seeds from the plant were scanned by NIRS, showing that most of them contained more than $60 \%$ oleate (Table 1), much higher than that in Huayu $22(51.10 \%)$. Three of the seeds (seed serial no. 3, 8 and 29 ) identified by NIRS as with high oleate were further confirmed by GC (Table 1).

Table 1. Oleate contents (\%) of individual peanut seeds from 76-13D3-2 as predicted by NIRS and measured by GC.

\begin{tabular}{cccccc}
\hline Seed serial no. & NIRS & GC & Seed serial no. & NIRS & GC \\
\hline 1 & 60.00 & $-{ }^{*}$ & 18 & 55.59 & - \\
2 & 60.88 & - & 19 & 58.88 & - \\
3 & 65.80 & 68.20 & 20 & 63.31 & - \\
4 & 66.15 & - & 21 & 67.44 & - \\
5 & 68.69 & - & 22 & 62.34 & - \\
6 & 63.90 & - & 23 & 53.49 & - \\
7 & 64.28 & - & 24 & 59.11 & - \\
8 & 65.36 & 68.70 & 25 & 59.21 & - \\
9 & 64.95 & - & 26 & 65.01 & - \\
10 & 56.96 & - & 27 & 63.47 & - \\
11 & 61.16 & - & 28 & 59.35 & - \\
12 & 60.45 & - & 29 & 68.41 & 68.50 \\
13 & 61.86 & - & 30 & 63.58 & - \\
14 & 59.96 & - & 31 & 60.06 & - \\
15 & 58.34 & - & 32 & 61.31 & - \\
16 & 52.84 & - & 33 & 50.05 & - \\
17 & 60.58 & - & 34 & 58.89 & - \\
\hline
\end{tabular}

*Not measured by GC.

\section{Cloning and sequence analysis of FAD2B gene}

Sequences of the bF19/R1 primed PCR products of the three high oleate peanut seeds had no difference. Comparison of the FAD2B gene sequence from normal oleate peanut cultivar Huayu 22 and from high oleate peanut seeds showed a $\mathrm{C}$ to $\mathrm{T}$ transition in 281 position of the coding region (Figure 2 ), which caused an 194T (isoleucine to threonine) mutation in the amino acid sequences of the desaturase in high oleate mutant (Figure 3). This amino acid substitution located in the hydrophobic region.

\section{CONCLUDING REMARKS AND DISCUSSION}

The study demonstrated the feasibility of chemical mutagenesis for peanut high oleate breeding with the help of NIRS. As compared with hybridization, direct selection of high yielding adapted peanut cultivars as the target for mutagenesis may speed up the progress in developing high oleate peanut varieties. 
Different from previously reported mutations in FAD2B gene (Yu et al. 2008; Chu et al. 2009), in the present study, a C281T transition in the coding regionof FAD2B in peanut seeds with elevated oleate caused an 194T substitution in the oleoyl-PC desaturase, which may be responsible for reduction in enzyme activity. To test this hypothesis, expressing the mutated gene in a different system and checking for changes in oleate/linoleate content are still needed.

In addition to the NIRS equations for fatty acids, NIRS equations for peanut oil and protein have also been developed by us thus far, which enable multiple internal quality traits to be selected simultaneously, rapidly and non-destructively. Pyramiding multiple quality traits in one adapted high yielding cultivar may pave the way to a breakthrough in peanut quality breeding.

Financial support: The authors thank support from the earmarked fund for Modern Agro-industry Technology Research System (MATRS) Peanut Program (Grant No. nycytx-19), Ministry of Agriculture, China, 863 New and High Technology Project (Grant No. 2006AA10A114), Qingdao Science \& Technology Support Program (Grant No. 10-3-3-20-nsh), Shandong Natural Science Foundation (Grant No. Y2008D11), and Shandong Key Project of Science \& Technology (Grant No.2009GG10009008).

\section{REFERENCES}

CHU, Y.; ROMOS, L.; HOLBROOK, C.C. and OZIAS-AKINS, P. (2007). Frequency of a loss-of-function mutation in oleoyl-PC desaturase (ahFAD2A) in the mini-core of the U.S. peanut germplasm collection. Crop Science, vol. 47, no. 6, p. 2372-2378. [CrossRef]

CHU, Y.; HOLBROOK, C.C. and OZIAS-AKINS, P. (2009). Two alleles of ahFAD2B control the high oleic acid trait in cultivated peanut. Crop Science, vol. 49, no. 6, p. 2029-2036. [CrossRef]

ISLEIB, T.G.; WILSON, R.F. and NOVITZKY, W.P. (2006). Partial dominance, pleiotropism, and epistasis in the inheritance of the high-oleate trait in peanut. Crop Science, vol. 46, no. 3, p. 1331-1335. [CrossRef]

JUNG, S.; SWIFT, D.; SENGOKU, E.; PATEL, M.; TEULÉ, F.; POWELL, G.; MOORE, K. and ABBOTT, A. (2000). The high oleate trait in the cultivated peanut [Arachis hypogaea L.]. I. Isolation and characterization of two genes encoding microsomal oleoyl-PC desaturases. Molecular and General Genetics MGG, vol. 263, no. 5, p. 796-805. [CrossRef]

LOPEZ, Y.; SMITH, O.D.; SENSEMAN, S.A. and ROONEY, W.L. (2001). Genetic factors influencing high oleic acid content in Spanish market-type peanut cultivars. Crop Science, vol. 41, no. 1, p. 51-56. [CrossRef]

MONDAL, S.; BADIGANNAVAR, A.M. and D'SOUZA, S.F. (2010). Induced variability for fatty acid profile and molecular characterization of high oleate mutant in cultivated groundnut (Arachis hypogaea L.). Plant Breeding, Early View. [CrossRef]

NORDEN, A.J.; GORBET, D.W.; KNAUFT, D.A. and YOUNG, C.T. (1987). Variability in oil quality among peanut genotypes in the Florida breeding program. Peanut Science, vol. 14, no. 1, p. 7-11. [CrossRef]

O'BYRNE, D.J.; KNAUFT, D.A. and SHIREMAN, R.B. (1997). Low fat monounsaturated rich diets containing high oleic peanuts improve serum lipoprotein profiles. Lipids, vol. 32, no. 7, p. 687-695. [CrossRef]

PATEL, M.; JUNG, S.; MOORE, K.; POWELL, G.; AINSWORTH, C. and ABBOTT, A. (2004). High-oleate peanut mutants result from a MITE insertion into the FAD2 gene. TAG Theoretical and Applied Genetics, vol. 108, no. 8, p. 1492-1502. [CrossRef]

TILLMAN, B.; GORBET, D. and PERSON, G. (2006). Predicting oleic and linoleic acid content of single peanut seeds using near-infrared reflectance spectroscopy. Crop Science, vol. 46, no. 5, p. 2121-2126. [CrossRef]

YU, S.L.; PAN, L.J.; YANG, Q.L.; MIN, P.; REN, Z.K. and ZHANG, H.S. (2008). Comparison of the $\Delta^{12}$ fatty acid desaturase gene between high-oleic and normal-oleic peanut genotypes. Journal of Genetics and Genomics, vol. 35, no. 11, p. 679-685. [CrossRef]

YU, S.T.; WANG, C.T.; YU, S.L.; WANG, X.Z.; TANG, Y.Y.; CHEN, D.X. and ZHANG, J.C. (2010). Simple method to prepare DNA templates from a slice of peanut cotyledonary tissue for polymerase chain reaction. Electronic Journal of Biotechnology, vol. 13, no. 4. [CrossRef]

WANG, C.T.; YU, S.L.; ZHANG, S.W.; WANG, X.Z.; TANG, Y.Y.; ZHANG, J.C. and CHEN, D.X. (2010). Novel protocol to identify true hybrids in normal oleate $\mathrm{x}$ high oleate crosses in peanut. Electronic Journal of Biotechnology, vol. 13, no. 5. [CrossRef]

ZEILE, W.L.; KNAUFT, D.A. and KELLY, C.B. (1993). A rapid non-destructive technique for fatty acid determination in individual peanut seed. Peanut Science, vol. 20, no. 1, p. 9-11. [CrossRef] 


\section{How to cite this article:}

WANG, C.T.; YUE YI TANG, Y.Y.; WANG, X.Z.; ZHANG, S.W.; LI, G.J.; ZHANG, J.C. and YU, S.L. (2011). Sodium azide mutagenesis resulted in a peanut plant with elevated oleate content. Electronic Journal of Biotechnology, vol. 14, no. 2. http://dx.doi.org/10.2225/vol14-issue2-fulltext-4

Note: Electronic Journal of Biotechnology is not responsible if on-line references cited on manuscripts are not available any more after the date of publication. Supported by UNESCO / MIRCEN network. 